\title{
Rural-Urban Differences in Characteristic and Lipid Profile Among Javanese Ethnic of Type 2 Diabetes Patients
}

\author{
Yanuarita Tursinawati ${ }^{1, *}$ Arum Kartikadewi ${ }^{1}$ Ari Yuniastuti ${ }^{2}$ R. Susanti ${ }^{2}$ \\ ${ }^{1}$ Biomedical Departement Muhammadiyah University Semarang \\ ${ }^{2}$ Biology Departement, University State of Semarang \\ *Corresponding author. Email: yanuarita_tursina@unimus.ac.id
}

\begin{abstract}
Background: Urbanization has led to changes in human health with the inception of non-communicable diseases such as Diabetes mellitus (DM). This is generally due to the adaptation to unhealthy and sedentary lifestyles, with poor diet patterns. The purpose of this research is to identify the rural and urban differences in characteristics and lipid profile among the Javanese ethnic of Type 2 Diabetes patients. Method: This was an observational analytic study, with the cross-sectional approach used to obtain data from 102 T2DM patients in Gunungpati (rural), Pandanaran and Purwoyoso Health Centers (urban). The characteristics assessed included age, sex, BMI, blood pressure, blood sugar levels and lipid profile. The BMI was calculated by dividing body weight in kg by body height in meters squared, based on the Asia Pacific criteria. The blood pressure was measured with a mercury sphygmomanometer, then the levels of FPG and lipid profile were taken after the patients fasted for the previous 8 hours. Furthermore, the Mann Whitney U test was used to test the characteristics differences with a significance value of $p \leqslant 0.05$.Results: There were significant differences between FPG control $(p=0.032)$ and HDL levels $(p=0.006)$. Meanwhile, characteristic data such as age ( $p$ $=0.214)$, gender $(\mathrm{p}=0.790)$, BMI $(\mathrm{p}=0.196)$, and blood pressure $(\mathrm{p}=0.123)$ did not have significant differences. Furthermore, insignificant results were also obtained at various levels of FPG $(p=0.917)$, cholesterol $(p=0.436)$, triglycerides $(\mathrm{p}=0.724)$, LDL $(\mathrm{p}=0.188)$, and Chol / HDL ratio $(\mathrm{p}=0.297)$. In urban areas, the average cholesterol levels $(185.59 \pm 52.59)$, HDL $(62.60 \pm 16.69 \mathrm{mg} / \mathrm{dl})$, LDL $(201.16 \pm 59,36 \mathrm{mg} / \mathrm{dl})$, were higher than those in the rural areas. Conclusion: In the urban group, FPG control was significantly worse than rural. Furthermore, cholesterol, HDL, LDL of Javanese T2DM patients in urban areas are higher than those in rural areas. However, only HDL is significantly different
\end{abstract}

Keywords: type 2 DM, rural, urban, Lipid profile

\section{INTRODUCTION}

The rural and urban communities in the modern world, both have different characteristics in terms of social function, heterogeneity of population, infrastructure and government. Individuals living in these areas even have differences in terms of morbidity and mortality rates. [1] Geographical locations also play an important role in disease distribution pattern; for example, there are variations in the diseases common in coastal and mountainous regions. [2] In addition, urbanization, which causes movement of people from rural to urban areas, seems to cause changes in people's lives, especially in terms of health. [3] It also has a direct impact on change in lifestyles which could lead to the emergence of non-communicable diseases such as diabetes mellitus (DM) and hypertension in urban areas. DM is a chronic metabolic disease caused by defect in either insulin secretion or action or both, marked with hyperglycemia. [4] The type 2 DM, which is the most common, is marked by insulin resistance. Pathophysiology of insulin resistance usually occurs due to mitochondrial dysfunction in fat tissue resulting to an increase in oxidative stress, apotosis and inflammation and ultimately, insulin resistance. [5] The risk factors for DM include: age, gender, genetics, smoking habits and dietary patterns. [6,7] DM could lead to serious issues due to uncontrolled blood glucose levels either in the form of macrovascular or microvascular complications. The macrovascular complications are in the form of heart and brain diseases, as well as stroke and diabetic foot, while the microvascular complications could occur in the kidneys (diabetic nephropathy), eyes (diabetic retinopathy, cataracts) and diabetic neuropathy. [8] Based on the Basic Health Research conducted by Riskesdas (2018), the prevalence of DM increased to $2 \%$ compared with the figures in 2013. [9] Based on doctors' diagnoses, the prevalence of DM in 2018 was $1.9 \%$ in 
urban areas and $1.0 \%$ in rural areas. According to the data from the Semarang City Health Office, DM is the second highest non-communicable disease in Semarang with an incidence of 15,250 cases in 2016.[10]

This condition is not only characterized by chronic hyperglycemia, but also a disturbance in fat, carbohydrate and protein metabolism due to defect in insulin secretion and / or insulin resistance. Serum lipid abnormalities, also known as dyslipidemia, are often found in diabetic patients. This is marked by increased lipoprotein cholesterol (LDL-C), decreased high-density lipoprotein cholesterol (HDL-C) levels, or increased triglycerides. Also, hypertriglycerides and low HDL are more commonly found in this condition compared with hypercholesterolaemia. [11] According to Sone et al. (2011), triglyceride levels are better predictors, compared with LDL-C levels, in the incidence of macrovascular complications in the form of coronary heart hisease among diabetes patients in Japan. [12] Additionally, Millan et al. (2009) showed that the higher cholesterol / HDL ratio, the higher the risk of cardiovascular disease due to an imbalance of cholesterol with protective and atherogenic lipoproteins. [13]

The patterns of diseases and differences in health status between rural and urban communities are influenced by various factors. For example, urbanization is often associated with socioeconomic changes which encourage people to adopt unhealthy lifestyles in terms of eating habits, alcohol consumption, smoking, sedentary lifestyles and reduced exercise due to tight schedules. [14] These contribute to the rise in the cases of DM in urban areas. However, these communities are better equipped in terms of health facilities for treating the condition. According to Anhar et al. (2016), the levels of health and treatments in rural communities are still very low compared with urban areas. This is seen from the low number of visits to the public health centers in rural communities compared with urban communities. [15] There are no studies that have compared the differences in the characteristics and lipid profiles of Javanese T2DM patients. Therefore this research aims to identify the rural and urban differences in characteristics and lipid profile among the Javanese ethnic of Type 2 Diabetes patients,which being the largest ethnic group in Indonesia.. The results of this study are expected to provide an overview for the management of T2DM based on the distribution area population of T2DM patients.

\section{RESEARCH METHOD}

This research was an analytic observational study with cross sectional approach involving a sample of 102 type $2 \mathrm{DM}$ (T2DM) patients. The study population was T2DM patients who had routine treatment at the Primary Health Center and underwent the Chronic Disease Management Program (Prolanis). Samples were those who fulfilled the inclusion criteria such as Javanese T2DM patients, aged 30-70 years and had signed informed consent form. The exclusion criteria include a history of cardiovascular disorders such as stroke, heart failure and acute myocardial infarction. The ethical permission for this research was granted by the Ethics Commission of the Medicine Faculty, University of Muhammadiyah Semarang with Number 040 / EC / FK / 2019. Data was collected between March-April 2019 in the Gunungpati Health Center (rural) and the Pandanaran and Purwoyoso Health Centers (urban).

Data obtained from primary data in the form of measurement of age Body Mass Index (BMI), blood pressure, Fasting Plasma Glucose (FPG), cholesterol, HDL triglycerides, LDL, and Chol / HDL ratio. The BMI was calculated by dividing body weight in $\mathrm{kg}$ by body height in meters squared, based on the Asia Pacific criteria. The blood pressure was measured with a mercury sphygmomanometer, then the levels of FPG and lipid profile were taken after the patients fasted for the previous 8 hours. Also, examination of FPG and lipid profile was conducted in the Semarang CITO laboratory. The data obtained were subjected to statistical analysis using SPSS, version 21.0 (SPPS Inc., Chicago, IL, USA). The categorical data were subjected to the Chi square test while numerical data were analyzed using the Mann Whitney $U$ test because the data distribution was not normal, with a significance value of $\mathrm{p} \leq 0.5$.

\section{RESULTS}

A total of 102 patients with type 2 diabetes were selected in three regions, namely Gunungpati Health Center (rural area) with 32 patients, and Pandanaran and Purwoyoso Health Centers (urban area) with 70 patients. The majority of subjects in the urban group were aged $>60$ years $(52.9 \%)$, female $(75.7 \%)$, with uncontrolled blood sugar levels $(77.1 \%)$, normal BMI (32.9\%), and prehypertension $(38.6 \%)$. However, the majority of the subjects in the rural group were aged $>60$ years $(34.4 \%)$, female $(78.1 \%)$, with uncontrolled blood sugar levels (56.3\%), normal BMI and Obese I (respectively 43.8\%), and prehypertension $(53.1 \%)$ as listed in table 1 . 
Table 1. Characteristic Data of Type 2 DM Patients in Rural and Urban Groups

\begin{tabular}{|c|c|c|c|}
\hline & \multicolumn{2}{|c|}{ Subjects $(\mathrm{n}=102)$} & \multirow[b]{2}{*}{$\mathrm{p}$} \\
\hline & $\begin{array}{c}\text { Urban } \\
\mathrm{n}=70\end{array}$ & $\begin{array}{l}\text { Rural } \\
\mathrm{N}=32\end{array}$ & \\
\hline \multicolumn{4}{|l|}{ Age (year) } \\
\hline $40-44$ & $1(1.3 \%)$ & $2(6.1 \%)$ & 0.214 \\
\hline $45-49$ & $3(4.3 \%)$ & $4(12.5 \%)$ & \\
\hline $50-54$ & $8(11.4 \%)$ & $5(15.6 \%)$ & \\
\hline $55-59$ & $21(30 \%)$ & $10(31.3 \%)$ & \\
\hline $60+$ & $37(52.9 \%)$ & $11(34.4 \%)$ & \\
\hline \multicolumn{4}{|l|}{ Gender } \\
\hline Male & $17(24.3 \%)$ & $7(21.9 \%)$ & \\
\hline Female & $53(75.7 \%)$ & $25(78.1 \%)$ & 0.790 \\
\hline \multicolumn{4}{|l|}{ Fasting Plasma Glucose Control } \\
\hline Uncontrolled $(<90$ or $>130 \mathrm{mg} / \mathrm{dl})$ & $54(77.1 \%)$ & $18(56.3 \%)$ & $0.032^{*}$ \\
\hline Controlled $(90-130 \mathrm{mg} / \mathrm{dl})$ & $16(22.9 \%)$ & $14(43.8 \%)$ & \\
\hline \multicolumn{4}{|l|}{ Body Mass Index (Asia Pacific) } \\
\hline Underweight $\left(<18.5 \mathrm{~kg} / \mathrm{m}^{2}\right)$ & $2(2.9 \%)$ & $0(0 \%)$ & \\
\hline Normal $\left(18.5-22.9 \mathrm{~kg} / \mathrm{m}^{2}\right)$ & $23(32.9 \%)$ & $14(43.8 \%)$ & \\
\hline Overweight $\left(23-24.9 \mathrm{~kg} / \mathrm{m}^{2}\right)$ & $16(22.9 \%)$ & $3(9.4 \%)$ & 0.196 \\
\hline Obese I ( $\left.25-29.9 \mathrm{~kg} / \mathrm{m}^{2}\right)$ & $22(31.4 \%)$ & $14(43.8 \%)$ & \\
\hline Obese II $(\geq 30 \mathrm{~kg} / \mathrm{m} 2)$ & $7(10 \%)$ & $1(3.1 \%)$ & \\
\hline \multicolumn{4}{|l|}{ Hypertention (JNC VII) } \\
\hline Normal & $8(11.4 \%)$ & $2(6.3 \%)$ & \\
\hline Prehypertension & $27(38.6 \%)$ & $17(53.1 \%)$ & \\
\hline Hypertension gr 1 & $26(37.1 \%)$ & $9(28.1 \%)$ & 0.123 \\
\hline Hypertension gr 2 & $8(11.4 \%)$ & $1(3.1 \%)$ & \\
\hline Crisis Hypertension & $1(1.4 \%)$ & $3(9.4 \%)$ & \\
\hline
\end{tabular}

Comparing the characteristic data between the urban and rural groups, there was a significant difference between the groups in the controlling of FPG levels, with $\mathrm{p}=0.032$, as shown in Table 1 and HDL levels, with $\mathrm{p}=$ 0.006 , as shown in Table 2. However, other characteristics such as age $(\mathrm{p}=0.214)$, gender $(\mathrm{p}=$ $0.790)$, BMI $(p=0.196)$, blood pressure $(p=0.123)$, FPG levels $(\mathrm{p}=0.917)$, cholesterol $(\mathrm{p}=0.436)$, triglycerides $(p=0.724)$, LDL $(p=0.188)$, and the Chol / HDL ratio $(\mathrm{p}=0.297)$, as listed in tables 1 and 2 . In the urban group, the average cholesterol level was $185.59 \pm 52.59 \mathrm{mg} / \mathrm{dl}$, HDL (62.60 $\pm 16.69 \mathrm{mg} / \mathrm{dl})$, LDL (201.16 $\pm 59.36 \mathrm{mg}$ / dl), which were higher than the rural group.

\section{DISCUSSION}

The diagnosis of DM is usually made when the FPG levels > $126 \mathrm{mg} / \mathrm{dl}$ or blood sugar is $>200 \mathrm{mg} / \mathrm{dl}$. [16] Based on this research, the average FPG level in the rural group was higher than the urban group, although not statistically significant. This is in line with a previous study which showed that the prevalence of DM in rural areas of most developing countries was higher compared with urban areas. [17] The insignificant results of FPG between the two groups are in line with research of Tasmini et al. (2018), which analyzed the levels of FPG in rural and urban populations in Yogyakarta. This research showed that there was no significant difference $(\mathrm{p}=0.385)$, between the residents in these two regions, with higher percentage with higher FPG levels were in the rural area. [18]

The insignificant results in this study might be due to the average FPG level in the rural group which was almost the same as the urban group. Increased FPG levels in T2DM patients could be due to factors such as educational level, socioeconomic status, access to health services, and utilization of modern health facilities. A

Table 2. Lipid Profile of T2DM Patients in Rural and Urban Groups

\begin{tabular}{|c|c|c|c|c|c|c|c|}
\hline \multirow[t]{2}{*}{ Characteristic } & \multicolumn{3}{|c|}{ Urban } & \multicolumn{3}{|c|}{ Rural } & \multirow[t]{2}{*}{$\mathbf{p}$} \\
\hline & Mean & Median & $\begin{array}{l}\text { Minimum- } \\
\text { maximum }\end{array}$ & Mean & Median & $\begin{array}{l}\text { Minimum- } \\
\text { maximum }\end{array}$ & \\
\hline BMI & $24.47 \pm 3.5$ & 23.95 & $17.3-33.3$ & $24.1 \pm 3.1$ & 23.6 & $19.1-30.5$ & 0.586 \\
\hline FPG (mg/dl) & $160.49 \pm 74.51$ & 146 & $60-365$ & $160 \pm 70.90$ & 128.5 & $85-340$ & 0.917 \\
\hline Cholesterol (mg/dl) & $185.59 \pm 52.59$ & 192.5 & $41-314$ & $174.16 \pm 60.76$ & 202.5 & $58-266$ & 0.436 \\
\hline Triglycerides (mg/dl) & $203 \pm 158.76$ & 166 & $76-1340$ & $\begin{array}{l}206.28 \pm \\
103.00\end{array}$ & 179.50 & $61-532$ & 0.724 \\
\hline HDL (mg/dl) & $62.60 \pm 16.69$ & 62 & 33-109 & $53.47 \pm 13.35$ & 54 & $33-97$ & $0.006^{*}$ \\
\hline $\mathrm{LDL}(\mathrm{mg} / \mathrm{dl})$ & $201.16 \pm 59.36$ & 208 & $87-343$ & $186.06 \pm 45.80$ & 172.5 & $109-279$ & 0.188 \\
\hline Chol/HDL ratio & $4.77 \pm 1.37$ & 4.6 & $2.6-9.7$ & $5.00 \pm 1.35$ & 4.7 & $2.6-8.4$ & 0.297 \\
\hline
\end{tabular}


research in Korea by Lee HY et al. (2010) showed the significant relationship between low socioeconomic status and the incidence of T2DM in urban communities. Based on the study, the income of subjects with T2DM was significantly lower compared with non-type 2 DM. [19] Another research in Myanmar showed the highest incidence of DM among subjects with low educational status in urban communities. [20] According to Anhar et al. (2016), there is still a low utilization of health services in rural communities. [15] This is due to the low community awareness in checking their health status. Some of these patients might be reluctant to check their glucose levels or even take drugs provided by the health center, which could be responsible for the higher levels of FPG. Level of education is also a determinant of DM. Low education could affect the awareness level to have the disease checked, which is also associated with low access to health services, as well as information about DM and related lifestyles. [21] Access to health services also plays a significant role in the incidence of DM. According to Aung WP et al. (2018), the majority of subjects which check their FPG levels are from the urban groups. [20] However, without proper health checks, patients in urban areas could still have high levels of FPG. Urban populations are preoccupied with work activities, therefore they do not have enough time for medical checks. T2DM is characterized by insulin resistance where there is a decrease in cellular response to insulin. Several studies have shown the association between insulin resistance and chemicals such as phthalates and bisphenol A (BPA), which are some of the environmental pollutants present in urban areas. [22,23] Experimental studies on animals have shown that insulin sensitivity is also influenced by nitrogen dioxide (NO2) and PM 2.5 in air pollutants often found in urban areas. [24] Therefore, exposure to pollutants in urban areas is one of the causes of DM incidence.

In order to achieve an optimal metabolic control, a DM patient needs to adopt a change in lifestyle. The needed parameters to determine the optimal glycemic control are the HbAIc and fasting sugar levels examination. The target of fasting blood glucose level in DM patients is in the range of $90-130 \mathrm{mg} / \mathrm{dl}$. [25] Some studies have shown that controlling the glycemic level of DM patients in the urban group was significantly worse than the rural group. The results of this study are in line with the research conducted in Xinjiang, China, which proved the difficulty in glycemic control in urban communities compared with rural areas. [26] However, Fiseha T et al. (2018) showed that poor glycemic control was more significant among patients in the rural areas compared with the urban. [27] Poor control in urban communities could be associated with unhealthy lifestyles such as lack of physical activity and poor dietary or eating habits. Poor eating habits such as frequent consumption of foods high in carbohydrates, fats, as well as fast foods, which are all at greater risk of causing diabetes. [28,29] Additionally, community migration from rural to urban areas usually comes with health problems including obesity and DM. Sobngwi et al. (2004) also showed the connection between urban lifestyles and the incidence of obesity and diabetes in Cameroon. The same study further proved that there was a significant relationship between urban lifestyle and blood sugar levels, blood pressure and BMI. These urban lifestyles include sedentary activity, bad dietary habits and psychological stress. [30] Moreover, poor glycemic control is significantly affected by the duration of illness, nutritional status, medication adherence and distance of health facilities. [31] Regular control of blood sugar could prevent the emergence and progression of both micro and macrovascular complications.

Furthermore, this study proves that BMI in the urban groups was higher than rural, although with no significant difference. This is not line with the studies on T2DM conducted in Xinjiang, China and in Rwanda, where there were significant differences in the BMI between rural and urban groups. [26,32] The BMI in urban groups was significantly higher with the prevalence of overweight and obesity compared with the rural groups. [26] This was due to unhealthy lifestyles and eating habits already mentioned above. The lipid profile showed that the urban group had higher levels of cholesterol, triglycerides, HDL, and LDL compared with the rural. However, only HDL significantly differed between the groups, while the triglycerides, cholesterol, LDL and Col / HDL ratio showed no significant differences. This is in line with the study conducted by Du GL et al. (2016) where only HDL was significantly higher in the urban group compared to the rural.[26] DM is often followed by interference in the patient's lipid profile, a condition known as diabetic dyslipidemia or diabetes lipidus. According to the National Cholesterol Education Program (NCEP) and AHA, the dyslipidemia criteria includes the occurrence of an increase in total cholesterol $\geq 200 \mathrm{mg} / \mathrm{dl}, \mathrm{LDL}-\mathrm{C} \geq 130 \mathrm{mg} / \mathrm{dl}$, triglycerides $>150$ $\mathrm{mg} / \mathrm{dl}$ and HDL-C <35 mg / dl. [33,34] This condition is a major risk factor for macrovascular complications in T2Dm patients. Based on a study by Bali K et al. (2016) in Punjab, it was found that $81.8 \%$ of the subjects had dyslipidemia which could increase the prevalence of coronary artery disease (CAD).[35] The pattern of this dyslipidemia in T2DM patients usually shows an increase in triglycerides and LDL, as well as a decrease in HDL. In like manner, the results of this research show that there was an increase in triglycerides and LDL; however, there was no reduction in the level of HDL. The two abnormalities such as hypertriglyceride and increased LDL are strong risk factors for Cardiovascular disease cases. [35]

The cholesterol / HDL ratio parameter could also be used as a predictor of macrovascular complications. This study showed that the col / HDL ratio was higher in the rural groups compared with the urban groups, although not statistically significant. This is in contrast to the study conducted by Joshi et al. (2014) which showed a significantly higher col / HDL ratio in the urban group. This difference might be due to the use of general 
population in the 2014 research while T2DM were purely used in this current study. [36]

There are some of the weaknesses identified in this study; which include the levels of education and income of the subjects from both groups, which were not deeply analyzed for better comparison. In addition, there is need for deeper analysis on physical activity, medication adherence, access to health services. Therefore, there is need for further research to understand the comprehensive effects of these parameters.

\section{CONCLUSION}

In the urban group, FPG control was significantly worse than rural. Furtehermore, cholesterol, HDL, LDL of Javanese T2DM patients in urban areas are higher than those in rural areas. However, only HDL is significantly different.

\section{ACKNOWLEDGMENT}

We thank to the Directorate of Research and Community Services, Directorate General of Research and Development, Ministry of Research, Technology, and Higher Education, the Republic of Indonesia, under the research scheme of Penelitian Kerjasama Antar Perguruan Tinggi, 2019 No. 7/E/KPT/2019 for funding.

\section{REFERENCES}

[1] Chandra B. Ilmu Kedokteran Pencegahan dan Komunitas. Jakarta: EGC; 2009.

[2] Budiarto E. Pengantar epidemiologi. Jakarta: EGC; 2002.

[3] Goryakin Y, Rocco L, Suhrcke M. The contribution of urbanization to non-communicable diseases: Evidence from 173 countries from 1980 to 2008. Econ Hum Biol [Internet]. 2017;26:151-63. Available from: http://dx.doi.org/10.1016/j.ehb.2017.03.004

[4] Association AD. ADA Diagnosis and Classification of Diabetes Mellitus. Diabetes Care. 2010;33:62-9.

[5] Jimenéz-Aranda A, Fernández-Vázquez G, Mohammad A-Serrano M, Reiter RJ, Agil A. Melatonin improves mitochondrial function in inguinal white adipose tissue of Zücker diabetic fatty rats. J Pineal Res. 2014;57(1):103-9.

[6] Yin Y, Han W, Wang Y, Zhang Y, Wu S, Zhang H, et al. Identification of risk factors affecting impaired fasting glucose and diabetes in adult patients from northeast China. Int $\mathrm{J}$ Environ Res Public Health. 2015;12(10):12662-78.

[7] Tursinawati Y, Kartikadewi A, Hakim RF. Association of CAPN10 SNP-19 (rs3842570) Polymorphism on Fasting Plasma Glucose, Blood
Pressure and Body Mass Index of Javanese Type-2 Diabetes Patients. In: IOP Conference Series: Earth and Environmental Science. 2019. p. 011003.

[8] Khorsand M, Akmali M, Sharzad S, Beheshtitabar M. Melatonin reduces cataract formation and aldose reductase activity in lenses of streptozotocininduced diabetic rat. Iran $\mathbf{J}$ Med Sci. 2016;41(4):305-13.

[9] Kementerian Kesehatan RI. Hasil Riset Kesehatan Dasar 2018. Pusat Data dan Informasi Kementrian Kesehatan RI. Kementerian Kesehatan RI.; 2019. 1$8 \mathrm{p}$.

[10] Kementerian Kesehatan Republik Indonesia. Profil Kesehatan Indonesia 2016. Kementerian Kesehatan Republik Indonesia; 2017.

[11] Hirano T. Pathophysiology of diabetic dyslipidemia. J Atheroscler Thromb 2018;25(9):771-82.

[12] Sone H, Tanaka S, Tanaka S, Iimuro S, Oida K, Yamasaki Y, et al. Serum level of triglycerides is a potent risk factor comparable to LDL cholesterol for coronary heart disease in Japanese patients with type 2 diabetes: Subanalysis of the Japan Diabetes Complications Study (JDCS). J Clin Endocrinol Metab. 2011;96(11):3448-56.

[13] Jesús Millán , Xavier Pintó, Anna Muñoz, Manuel Zúñiga, Joan Rubiés-Prat, Luis Felipe Pallardo, Luis Masana, et al. Lipoprotein Ratios: Physiological Significance and Clinical Usefulness in Cardiovascular Prevention. Vasc Heal Risk Manag. 2009;5:757-65

[14] Allender S, Lacey B, Webster P, Rayner M, Deepa $\mathrm{M}$, Scarborough $\mathrm{P}$, et al. Level of urbanization and noncommunicable disease risk factors in Tamil Nadu, India. Bull World Health Organ. 2010;88(4):297-304.

[15] Anhar, Ahmad LOAI IC. Comparative Study of Utilization of Health Services in the Rural Community in Working Area of Local Government Clinic of West Poleang and the Urban Community in Working Area of Local Government Clinic of in 2015 Lepo-lepo. J Ilm Mhs Kesehat [Internet]. 2016;1(2):1-13. Available from: media.neliti.com

[16] Association. AD. Definition And Description of Diabetes Other Categories Of Glucose. Diabetes Care. 2010;33:62-9.

[17] WildS,RoglicG,GreenA,SicreeR K. Global prevalence of diabetes: estimates for the year 2000 and projections for 2030. Diabetes Care. 2004;27(5):1047-53. 
[18] Tasmini T, Farmawati A, Sunarti S, Hastuti P, Sadewa AH, Prasetyastuti P, et al. Kadar glukosa darah dan tekanan darah pada penduduk pedesaan dan perkotaan di Daerah Istimewa Yogyakarta. J Community Empower Heal. 2018;1(1):45-53.

[19] Lee HY, Won JC, Kang YJ, Yoon SH, Choi EO, Bae JY, et al. Type 2 diabetes in urban and rural districts in Korea: Factors associated with prevalence difference. J Korean Med Sci. 2010;25(12):177783.

[20] Aung WP, Htet AS, Bjertness E, Stigum H, Chongsuvivatwong V, Kjøllesdal MKR. Urbanrural differences in the prevalence of diabetes mellitus among 25-74 year-old adults of the Yangon Region, Myanmar: Two cross-sectional studies. BMJ Open. 2018;8(3):1-9.

[21] Agardh E, Allebeck P, Hallqvist J, Moradi T, Sidorchuk A. Type 2 diabetes incidence and socioeconomic position: A systematic review and metaanalysis. Int J Epidemiol. 2011;40(3):804-18.

[22] Thanikachalam M, Fuller $\mathrm{CH}$, Lane KJ, Sunderarajan J, Harivanzan V, Brugge D, et al. Urban environment as an independent predictor of insulin resistance in a South Asian population. Int $\mathbf{J}$ Heal Geogr [Internet]. 2019;18(1):1-9. Available from: https://doi.org/10.1186/s12942-019-0169-9

[23] Hectors TL, Vanparys C, Van Gaal LF, Jorens PG, Covaci A BR. Insulin resistance and environmental pollutants: experimental evidence and future perspectives. Env Heal Perspect. 2013;121(1112):1273-81.

[24] Chen Z, Salam MT, Toledo-Corral C, Watanabe RM, Xiang AH B, TA et al. Ambient air pollutants have adverse effects on insulin and glucose homeostasis in Mexican Americans. Diabetes Care. 2016;39(4):547-54.

[25] V F. Clinical significance of targeting postprandial and fasting hyperglycemia in managing type 2 diabetes mellitus. Cur Med Res Opin. 2003;19(7):635-41.

[26] Du GL, Su YX, Yao H, Zhu J, Ma Q, Tuerdi A, et al. Metabolic risk factors of type 2 diabetes mellitus and correlated glycemic control/ complications: A cross-sectional study between rural and urban uygur residents in xinjiang uygur autonomous region. PLoS One. 2016;11(9):1-18.

[27] Fiseha T, Alemayehu E, Kassahun W, Adamu A, Gebreweld A. Factors associated with glycemic control among diabetic adult out-patients in Northeast Ethiopia. BMC Res Notes [Internet]. 2018;11(1):4-9. Available from: https://doi.org/10.1186/s13104-018-3423-5
[28] Rahati S, Shahraki M, Arjomand G, Shahraki T. Food Pattern, Lifestyle and Diabetes Mellitus. Int J High Risk Behav Addict. 2014;3(1):1-5.

[29] Sami W, Ansari T, Butt NS, Rashid M, Hamid A. Effect Of Diet Counseling On Type 2 Diabetes Mellitus. Int J Heal Sci. 2015;4(8):112-8.

[30] Sobngwi E, Mbanya JC, Unwin NC, Porcher R, Kengne AP, Fezeu L, et al. Exposure over the life course to an urban environment and its relation with obesity, diabetes, and hypertension in rural and urban Cameroon. Int J Epidemiol. 2004;33(4):769_ 76.

[31] Yulia R, Artawan PIWG, Putra E, Wirawan DN, Yulia R, Artawan PIWG, et al. Faktor Risiko Kendali Glikemik Buruk pada Penderita Diabetes Melitus Tipe 2 di Puskesmas Kembiritan Kabupaten Banyuwangi Risk Factors Poor Glycemic Control among Patients with Type 2 Diabetes Mellitus at the Primary Health Center of Kembiritan Banyuwangi. PHPMA [Internet]. 2015;3(1):81-7. Available from:

http://ojs.unud.ac.id/index.php/phpma/article/down load/16677/10952

[32] Charlotte Bavuma Munganyinka, Sanctus Musafiri, Pierre-Claver Rutayisire, Loise Mwihaki, Ruth McQuillan SHW. Socio-demographic and clinical characteristics of diabetes mellitus in rural Rwanda: Time to contextualize the interventions? A crosssectional study. BMC Endocr Disord. 2019;

[33] Kavey REW, Daniels SR, Lauer RM, Atkins DL, Hayman LL, Taubert K. American Heart Association guidelines for primary prevention of atherosclerotic cardiovascular disease beginning in childhood. Circulation. 2003;107(11):1562-6.

[34] Yang S, Hwang JS, Park HK, Lee HS, Kim HS, Kim EY, et al. Serum Lipid Concentrations, Prevalence of Dyslipidemia, and Percentage Eligible for Pharmacological Treatment of Korean Children and Adolescents; Data from the Korea National Health and Nutrition Examination Survey IV (2007-2009). PLoS One. 2012;7(12):1-8.

[35] Kusum Bali ASV. Pattern of dyslipidemia in Type 2 Diabetes Mellitus in Punjab. Int J Res Med Sci. 2016;4(3):1809-12.

[36] Joshi SR, Anjana RM, Deepa M, Pradeepa R, Bhansali A, Dhandania VK, et al. Prevalence of dyslipidemia in urban and rural India: The ICMRINDIAB study. PLoS One. 2014;9(5):1-9. 